DOI: $10.1515 / \mathrm{rpp}-2017-0023$

Lecturer, OLHA YAKOVCHUK

Motor Transport College of the State Higher Education Institution

"Kryvyi Rih National University"

Address: 19/23 Spaska St., 50049, Kryvyi Rih, Ukraine

E-mail: gluschenkoo@ukr.net

\title{
COMPARATIVE ANALYSIS OF UKRAINIAN AND FOREIGN SCHOLARS' VIEWS ON INTERPRETATION OF SUCH TERMS AS COMPETENCY, PROFESSIONAL COMPETENCY, PROFESSIONAL COMPETENCY OF TECHNICIANS IN FOOD TECHNOLOGY
}

\begin{abstract}
The article deals with a comparative analysis of the content of such terms as competency, competence and professional competency of technicians in food technology. Special attention has been given to domestic and foreign scholars' research findings on the matter in order to consider the genesis of the term "competency" and its spreading within Ukrainian and foreign pedagogy. Based on the comparison of European standards and the educational and qualification-based specification of technicians in food technology, we have shown the interdependence of the content between such terms as competency, professional competency and professional competency of technicians in food technology. In the content of such term as professional competency we have distinguished separate competences according to the production functions and typical tasks within professional activity of future technicians in food technology. We have revealed the significance of core competences in the structure of professional competency of future specialists in food technology.

Keywords: competency, professional competency, professional competency of technicians in food technology, structure of professional competency, general and scientific, social and personal, instrumental and special competences.
\end{abstract}

\section{INTRODUCTION}

The forming of highly qualified specialists competitive on the labour market is a prerequisite for Ukraine's entry into the European Educational Space. Modern standards of education define the new requirements for the competency of future technicians in food technology. Modernization of the education system in Ukraine provides for the revision of the best industrial practices available and determines the need for introduction of new ones. In this regard, the research on the content of such terms as competency, professional competency and professional competency of technicians in food technology is relevant in the works of Ukrainian and foreign scholars. Updating the content of education is impossible without the use of European standards in the process of future specialists' training. Determining the structure of professional competency of future technicians in food technology is essential for preparing the competitive specialist. Within Ukrainian and foreign pedagogical sciences, we may observe the absence of a common approach to determining core competences in the structure of professional competency of technicians in food technology. The contents of the structural components of professional competency must meet the requirements of educational qualification characteristics and state standards for training technicians in food technology, their production functions and typical tasks 
within their professional activity. The forming of professional competency of technicians in food technology and core competences in its structure should be concentrated on scientifically based theoretical and methodological foundations of future specialists' training.

\section{THE AIM OF THE STUDY}

The aim of the study is to analyze the content of such terms as competency, professional competency, professional competency of technicians in food technology based on the works of Ukrainian and foreign scholars.

\section{THEORETICAL FRAMEWORK AND RESEARCH METHODS}

While researching we have taken into consideration research findings of many foreign scholars. Among them we believe it necessary to mention N. Chomsky (1965) and D. Hymes (1975) who were first to use the term "competency"; J. Delors (1998) who investigated the need for education; P. Hager (1998) who considered philosophical arguments against competency standards; M. Mulder, T. Weigel \& K. Collins (2006) and E. Short (1995) who studied the concept of competence in the development of vocational education and training in selected EU member states; J. Raven (2002), T. Tomson \& J. Bonito (2007) who explored the modern model of competency; R. G. Sultana (2009) who jusitified competence and competence frameworks in career guidance. Among Ukrainian scholars it is necessary to highlight the work of O. Pometun (2005) who investigated the phenomenon of competency in its different aspects. In addition, we have taken into account the research findings by UNESCO.

During comparative research on the content of the above-mentioned terms we have used such methods as studying scientific and pedagogical sources and official documents, structural and genetic and comparative methods.

\section{RESULTS}

The European labour market requires competitive specialists qualified to perform professional tasks and production functions. In the modern world, the quality of training is not determined by the acquired knowledge, but it is the common theoretical foundation, which the future specialist should master. Therefore, the Council of Europe, UNESCO and the Department of International Standards have determined the content orientation of modern education toward self-development of personality, creativity, mobility and high communicative competency of future specialists.

The National Strategy for Development of Education in Ukraine by 2021 puts forward the strategic objectives and requirements for the level of professional training of experts in various fields. According to this document, changes in education should provide conditions for personal development due to their individual inclinations, abilities and training needs throughout life (Verkhovna Rada Ukrainy, 2013). The implementation of these requirements is impossible without constructing a model of the basic professional competencies and the forming of the body of knowledge and skills that would allow the future specialist to be competitive in the labour market.

For the first time the term "competency" was introduced into scientific circulation in the 1960-70s. So, the first who applied it were N. Chomsky (1965) (grammatical competency) and D. Hymes (1975) (communicative competency). Since the 1980s, the term "competency" has been used in professional education, management and law.

At that time, the works of J. Raven and other scholars appeared and they marked a new approach to interpreting the notion of competency. Exploring competency in modern society, J. Raven (2002) considers this term in many aspects: cognitive, emotional and 
behavioural. Thus, the definition of competency includes 37 components and personal characteristics. Analyzing the key competencies as the effectively-targeted basis of the competency-based approach in education, the Russian scholar I. Zimniaia (2004) uses this term in the meaning of the qualitative characteristics of the individual based on knowledge, intelligence and socially professional qualities of the person. Identical in the meaning with the term "competency", the researcher finds such definition as the willingness and ability to perform the action (Zimniaia, 2004). Subsequently, the term "competency" became general scientific and began to be used in different branches of knowledge.

At the beginning of the $21^{\text {st }}$ century, the competency-based approach in education was extended and it included mastering complex knowledge and skills, personal characteristics and behaviour, which contributed to the successful implementation of future specialists' professional activity. The education was aimed at forming professional competency, the content of which encompassed not only knowledge, but also a variety of expertise (Raven, 2002; Tomson \& Bonito, 2007).

Within this study we would like to analyze different definitions of the term "competency" that are common in modern scientific literature. The definition of competency has become widespread in native and foreign researches on pedagogy, psychology, economy, marketing, management etc. More often the term is used in the jurisprudential documents and law defining the duties of an organization or institution. Despite widespread use of the term "competency" in modern pedagogy, there is still no final opinion concerning this definition.

Translated from the Latin word "competentia" it means a range of issues in which an individual is knowledgeable or reputable (Online Etymology Dictionary, 2017). Longman Dictionary interprets the term "competency" as a range of issues in which an individual has some power, knowledge or experience (Longman Dictionary of Contemporary English Online, 2017). In Merriam-Webster, competency is defined as the ability of an individual to perform certain activities on the basis of experience, acquired knowledge and skills (Merriam-Webster, 2017).

The law of Ukraine "On Higher Education" defines the term "competency" as "a dynamic combination of knowledge, abilities and practical skills, ways of thinking, professional, philosophical and civic qualities, moral and ethical values that define an individual's ability to successfully implement professional and further training activities and it is the result of learning at a certain level of higher education"(Verkhovna Rada Ukrainy, 2014).

The concept of modern education development defines the competency of the specialist as an essential component of state education standards, the necessary basis for the forming of professional skills of future specialists (Mulder, Weigel \& Collins, 2006; E. Short, 1995).

It must be noted that E. Shorts' pedagogical ideas become rather popular within the global educational space. He believes that the term "competency" can be used in four meanings. Firstly, competency is a set of skills and abilities needed to conduct professional activity. Secondly, competency implies conscious mastering a certain profession. Thirdly, the scholar understands competency as a level of an individual's capabilities that corresponds to professional standards. Fourthly, competency is readiness for professional activity (Short, 1995).

International Commission on Education of UNESCO considers competency as "the general, basic key skills, fundamental ways of learning, principal conception or 
supportive knowledge". Therefore, J. Delors (1998) in his report "Learning: the treasure within" defined the main principles of education development. They are learning to know, learning to do, learning to be, learning to live together. To his opinion, these are key competencies aimed at achieving a high level of professional consciousness (UNESCO, 1996).

Ronald G. Sultana (2009) understands competency as a range of knowledge and skills. The structure of competency is divided into theoretical and practical components. P. Hager (1998) proposes to define the term "competency" as a set of intellectual, moral and social qualities of the individual. M. Mulder, T. Weigel \& K. Collins (2006) believe that competency is a set of theoretical knowledge, the ability to use the obtained knowledge and skills in practice. At the same time, they highlight the activity-based component of competency.

In scientific literature, along with the definition of competency, one can come across the term "professional competency". In pedagogical dictionaries, the term "professional competency" is interpreted as "the ability of the subject of labour to perform tasks or duties", "the forming of professionally important for an individual and society qualities that allow people to realize themselves in specific types of employment" (Pometun, 2005), "an integral quality of personality that manifests itself in the use of generalized skills", "an attitude towards successful professional activity", "the ability to perform certain tasks together with all knowledge and skills that are used in the implementation of labour operations", "possession of a set of professional knowledge and skills (competencies)", "a positive attitude to work" (Honcharenko, 2005), "the level of skill and professionalism of the specialist", "the ability to use their knowledge and skills in practice" (Bodalev, Derkach, Lapteva, 2002). Giving a scientific substantiation of the model of professional competency of the consultant, T. Thompson \& J. Bonito (2007) avoid the term "professional competency". In scientific use, researchers introduce their own definition of a system of professional competency and expertise".

We share the point of view of these researchers and think that the term "professional competency" is complicated. Under "professional competency" we understand a set of professionally significant qualities and personality traits that contribute to the successful implementation of tasks and responsibilities of the professional activity. Various competencies will be considered as components of the concept of professional competency.

New social demands on the quality of training service sector and the dynamic development of food industry of Ukraine have resulted in the appearance of researches where professional competencies of technicians for various industries are studied. Analysis of the content of the term "professional competency", which is found in the works of foreign and domestic researchers mentioned above, has given us the grounds to complement the meaning of professional competency of technicians in food technology. Working on creating models of their professional competency in the education process at colleges, we have introduced the term "professional competency of technicians in food technology" into the scientific use. Under this definition we understand the integrative quality characteristic of the expert, their ability to perform professional activities, which is a necessary requirement for the successful execution of production operations or functions. 
Forming of professional competency of technicians in food technology and acquisition of competencies must meet the functional duties and professional challenges of future specialists in the process of learning.

Also, we would like to analyze the European Standards of Professional Competency and the Basic Competences in its structure. In the project "Tuning Educational Structures in Europe" (2000) based on the goals and objectives of the education process, as well as the main types of educational and cognitive activity of students they have defined a list of key educational competences that allow developing knowledge, skills, social experience and practical skills in modern society (Tuning Educational Structures in Europe, 2000). A significant feature of Tuning is the choice to look at degrees in terms of learning outcomes and particularly in relation to competences. The Tuning project deals with two types of competences: generic competences (instrumental, interpersonal and systemic) and subject-specific competences (including skills and knowledge.) First and second cycles have been described in terms of agreed and dynamic reference points: learning outcomes and competences to be developed/achieved. The beautiful thing of comparable competences and learning outcomes is that they allow flexibility and autonomy in the construction of curricula. At the same time, they are the basis for formulating commonly understood level indicators. So, the structure of professional competency proposed in the project "Tuning Educational Structures in Europe" was the reason for the study of future specialists' competences (Tuning Educational Structures in Europe, 2000).

We believe that the structure of professional competency of technicians in food technology should be viewed through a set of competences, according to professional tasks and operational responsibilities of future specialists.

Technicians in food technology implement power saving technologies at the enterprises of public catering; determine the chemical composition and properties of raw materials, semi-finished products, finished products, comply with requirements for storage, control the quality of culinary products, carry out the basic calculations of processing. To perform these production functions, future specialists should possess basic theoretical knowledge, the forming of which is associated with general scientific competences. These competences describe the basic level of theoretical knowledge and intellectual development, contributing to an individual's ability to self-development and self-improvement.

In the process of carrying out functions the technicians in food technology communicate with different groups of consumers, agree on variety of production issues and solve conflicts, manage employees of production departments and divisions, coordinate and direct the activities of various departmentsof food production. Therefore, an integral component of forming professional competency of future technicians in food technology is socially and personal competence. It relates to the ability of critical and systems thinking, understanding and perception of the culture of behaviour, ethical standards of communication, provides an insight into the universal nature of the problems and requires adherence to a healthy lifestyle. An integral part of this competence is the level of communication skills formation that will enable specialists in food technology to organize the process through interpersonal communication.

In the production process technicians in food technology provide high quality work of technological equipment, carry out an inspection of various manufacturing processes, supervise the carrying out of works on exploration and development of new technological processes, control compliance with the rules of use of equipment, sanitary and hygiene requirements for catering businesses, work on a personal computer, using appropriate 
software, etc. The implementation of the above-mentioned production tasks is associated with the forming of instrumental competences. Using these competences technicians in food technology will be able to speak state and foreign languages, to develop skills of working in computer networks using the Internet resources, to apply a variety of processing skills and information management.

During the forming of social and personal, general scientific and instrumental competences technicians in food technology obtain basic knowledge of fundamental and professionally oriented disciplines in the volume necessary for the acquisition of special knowledge and professional competency. In the future, they are able to form professional competency of future specialists in the process of studying professionally oriented disciplines.

While performing the production tasks technicians in food technology develop and approve new recipes, apply knowledge of different treatment technologies of fruit and vegetable production, establish the causes of lack of raw materials and ready-made meals, improve the manufacturing of products, improve methods of quality control, identify incorrect activities during the process of implementing technological processes and make proposals for their elimination. In addition, technicians in food technology should apply acquired professional competences during their training (general professional and specialized professional). We believe that the forming of professional competences should belong to an important place in the structure of the competency of technicians in food technology. They reflect the requirements to level of future specialists' training; determine the professionally important qualities of their personality, characterize the ability to use basic theoretical knowledge in future production activities.

Consequently, the structure of professional competency of future technicians in food technology consists of four interrelated sets of competences: general scientific, social and personal, instrumental and professional. These competences are associated with the general requirements to future career of specialists, specify other structural components of professional competency; provide technicians in food technology with the knowledge of methods and the basics of the technological process in future production activities.

\section{CONCLUSIONS}

Thus, foreign and Ukrainian scholars interpret the meaning of the term competencey in different ways. Under the competency most scholars understand the body of knowledge and skills, whichare acquired during the education process and are necessary for effective professional activity of future specialists. Professional competency is seen as a set of professionally significant qualities and personality traits that contribute to the implementation of production functions and tasks of activity. In the pedagogical research, professional competency of technicians in food technology is linked with professional training of future specialists and is a necessary requirement for effective and successful implementation of their manufacturing activities and functions.

Rather perspective we consider the detailed study of competency-based approach in foreign literature.

\section{REFERENCES}

1. Bodalev, A., Derkach, A., \& Lapteva, L. (2002). Robochaia kniga prakticheskogo psikhologa: posobie dlia spetsialistov rabotaiushchikh $s$ personalom. Moscow: Izdatelstvo Instituta psikhoterapii.

2. Chomsky, N. (1965). Aspects of the Theory of Syntax. Cambridge: M.I.T Press. 
3. Delor, Zh. (1997). Obrazovanie - sokrytoe sokrovishche. UNESCO, 1996. Universitetskaya kniga, 4,37 .

4. Hager, P. (1998). Is there a cogent philosophical argument against competency standards? In P. Hirst and P. White (Eds.), Philosophy of education: major themes in the analytic: problems of 59 educational content and practices (Vol. 4, pp. 399-415). Florence, KY, USA: Routledge.

5. Honcharenko, S. I. (2000). Profesiina osvita: slovnyk. Kyiv: Vyshcha shkola.

6. Hymes, D. (1975). Etnografiya rechi. Novoe v lingvistike, 7, 42-95.

7. Longman Dictionary of Contemporary English Online. (2017). Retrieved from http://www.ldoceonline.com/dictionary/competence

8. Merriam-Webster. (2017). Retrieved from https://www.merriamwebster.com/dictionary/competency.

9. Mulder, M., Weigel, T. \& Collins, K. (2006). The concept of competence in the development of vocational education and training in selected EU member states. A critical analysis. Journal of vocational education and training, 59 (1), 67-88.
10. Online
Etymology
Dictionary.
(2017).
Retrieved from

http://www.etymonline.com/index.php?term=competence.

11. Pometun, O. I. (2005). Formuvannia hromadianskoi kompetentnosti: pohliad z pozytsii suchasnoi pedahohichnoi nauky. Visnyk prohram shkilnykh obminiv, 23, 18.

12. Raven, J. (2002). Kompetentnost v sovremennom obshchestve: vyyavlenie, razvitiye, realizatsiya. Moscow: Kogito-Tsentr.

13. Short, E. (1995). The concept of competence: its use and misuse in education. Journal of teacher education, 2, 2-6.

14. Sultana, R. G. (2009). Competence and competence frameworks in career guidance: complex and contested concepts. International journal for educational and vocational guidance, $9,15-30$.

15. Tomson, T., \& Bonito, J. (2007). Obzor modeli professionalnoi kompetentsii konsultanta. Retrieved from http://www.cfiN.ru/coNsultiNg/ccm.s.html.

16. Tuning Educational Structures in Europe. (2000). Retrieved from http:// www.unideusto. org/tuningeu/home.html.

17. UNESCO. (1996). Learning: the treasure within. Report to UNESCO of the International Comission on Education for the $21^{\text {st }}$ century. Retrieved from http://unesdoc.unesco.org/images/0010/001095/109590eo.pdf.

18. Verchovna Rada Ukrainy. (2013). Pro Natsionalnu stratehiiu rozvytku osvity $v$ Ukraini na period do $2021 \mathrm{roku}$. Vziato z http://zakon2.rada.gov.ua/laws/ show/344/2013.

19. Verkhovna Rada Ukrainy. (2014). Zakon Ukrainy "Pro vyshchu osvitu". Retrieved from http://zakon2.rada.gov.ua/laws/show/1556-18.

20. Zimniaia, I. A. (2004). Klyuchevyye kompetentnosti kak rezultativno-tselevaya osnova kompetentnostnogo podkhoda v obrazovanii. Moscow: Issledovatelskiy tsentr problem kachestva podgotovki spetsialistov. 